\title{
Genome Features and In Vitro Activity against Influenza $A$ and SARS-CoV-2 Viruses of Six Probiotic Strains
}

\author{
Irina V. Soloveva $\mathbb{D}^{1},{ }^{1}$ Tatyana N. Ilyicheva $\mathbb{D}^{2,3}$ Vasiliy Yu. Marchenko $\mathbb{D}^{2}{ }^{2}$ \\ Oleg V. Pyankov $\mathbb{D}^{2}$ Anna G. Tochilina $\mathbb{D}^{1},{ }^{1}$ Irina V. Belova $\mathbb{D}^{1},{ }^{1}$ Vladimir A. Zhirnov $\mathbb{D}^{1}{ }^{1}$ \\ Nikolay I. Bormotov, ${ }^{2}$ Maksim O. Skarnovich, ${ }^{2}$ Aleksander G. Durymanov $\mathbb{D}^{2}{ }^{2}$ \\ Svetlana B. Molodtsova $\left(\mathbb{D},{ }^{1}\right.$ Ekaterina I. Filippova, ${ }^{2}$ Alena S. Ovchinnikova, ${ }^{2}$ \\ Anastasia V. Magerramova, ${ }^{2}$ Alexander B. Ryzhikov $\mathbb{D}^{2}$ and Rinat A. Maksyutov $\mathbb{D}^{2}$
}

${ }^{1}$ Academician I.N. Blokhina Nizhny Novgorod Scientific Research Institute of Epidemiology and Microbiology, 71, M. Yamskaya Street, Nizhny Novgorod 603950, Russia

${ }^{2}$ Vector State Research Centre of Virology and Biotechnology, Koltsovo, Novosibirsk Region 630559, Russia

${ }^{3}$ Novosibirsk State University, 2, Pirogov Street, Novosibirsk 630090, Russia

Correspondence should be addressed to Irina V. Soloveva; lb-solovyeva@yandex.ru and Tatyana N. Ilyicheva; ilyichev@mail.ru Received 21 October 2020; Revised 7 April 2021; Accepted 29 May 2021; Published 24 June 2021

Academic Editor: San-Ji Gao

Copyright (c) 2021 Irina V. Soloveva et al. This is an open access article distributed under the Creative Commons Attribution License, which permits unrestricted use, distribution, and reproduction in any medium, provided the original work is properly cited.

\begin{abstract}
Purpose. The aim of this work was to analyze the complete genome of probiotic bacteria Lactobacillus plantarum 8 RA 3 , Lactobacillus fermentum 90 TC-4, Lactobacillus fermentum 39, Bifidobacterium bifidum 791, Bifidobacterium bifidum 1, and Bifidobacterium longum 379 and to test their activity against influenza A and SARS-CoV-2 viruses. Methods. To confirm the taxonomic affiliation of the bacterial strains, MALDI TOF mass spectrometry and biochemical test systems were used. Whole genome sequencing was performed on the Illumina Inc. MiSeq platform. To determine the antiviral activity, A/Lipetsk/1V/2018 (H1N1 pdm09) (EPI_ISL_332798) and A/common gull/Saratov/1676/2018 (H5N6) (EPI_ISL_336925) influenza viruses and SARS-CoV-2 virus strain Australia/VIC01/2020 (GenBank: MT007544.1) were used. Results. All studied probiotic bacteria are nonpathogenic for humans and do not contain the determinants of transmission-type antibiotic resistance and integrated plasmids. Resistance to antibiotics of different classes is explained by the presence of molecular efflux pumps of the MatE and MFS families. Cultures of L. fermentum 90 TC 4, L. plantarum 8 RA 3, and B. bifidum 791 showed a pronounced activity against influenza A viruses in MDCK cells. Activity against the SARS-CoV-2 virus was demonstrated only by the $L$. fermentum 90 TC 4 strain in VERO cells. Conclusions. The studied probiotic bacteria are safe, have antiviral activity, and are of great importance for the prevention of diseases caused by respiratory viruses that can also infect the human intestine.
\end{abstract}

\section{Introduction}

Probiotic bacteria have a number of unique properties and provide invaluable benefits to human health [1-3]. Lactoand bifidobacteria in the body carry out important functions. They participate in metabolism, produce biologically active compounds (vitamins, neuropeptides, bacteriocins, etc.), play a role in immunogenesis, and provide colonization resistance, and in addition, they exhibit antiviral activity against some viral pathogens in vitro and in vivo [4-7]. The main mechanisms of the inhibitory action of probiotic bacteria on viruses are a general immunostimulating effect of probiotic strains, physical adsorption of viral particles on the surface of bacteria where exopolysaccharides play an important role, specific interaction of probiotic bacteria with viral particles, and production of active metabolites $[7,8]$.

It is known that human respiratory viruses replicate mainly in the respiratory tract, and therefore, it is believed that probiotics cannot influence the dynamics of the disease. However, it has been described that during an influenza 
pandemic and sometimes during seasonal epidemics, gastrointestinal diseases caused by the influenza virus are observed, especially in children. In addition, when humans are infected with highly pathogenic avian influenza viruses [9] or the novel SARS-CoV-2 coronavirus [10], the pathogen also infects the intestines of the host. In this regard, the relevance of studying the antiviral activity of probiotic strains of lactoand bifidobacteria against respiratory viruses is beyond doubt.

The studied bacteria of the genera Lactobacillus and Bifidobacterium are used in Russia as probiotic producer strains. Their biological properties were investigated earlier using traditional microbiological and molecular genetic methods; however, whole genome sequencing of all strains has not been performed [11]. Analysis of the genomic sequences of the strains can confirm the safety of L. plantarum 8 RA 3, L. fermentum 90 TC 4, L. fermentum 39, B. bifidum 1, B. bifidum 791, and B. longum 379 bacteria for use as producers of probiotics and will also help to identify the determinants of antiviral activity.

The aim of this study was to analyze the genome-wide sequences of L. plantarum 8 RA 3, L. fermentum 90 TC 4, L. fermentum 39, B. bifidum 1, B. bifidum 791, and B. longum 379 probiotic bacteria and to study their antiviral activity against the $\mathrm{A}(\mathrm{H} 1 \mathrm{~N} 1 \mathrm{pdm} 09)$ influenza virus, the highly pathogenic influenza $A(\mathrm{H} 5 \mathrm{~N} 6)$ virus, and the SARS-CoV-2 virus that caused the COVID-19 pandemic.

\section{Materials and Methods}

2.1. Objectives. We studied bacteria used in Russia for the production of medicinal probiotics: Lactobacillus plantarum 8 RA 3 (State Collection of Pathogenic Microorganisms and Cell Cultures SCPM-Obolensk No. 900811), Lactobacillus fermentum 90 TC-4 (SCPM-Obolensk No. 900812), Lactobacillus fermentum 39 (SCPM-Obolensk \# 790039), Bifidobacterium bifidum 791 (Bioresource Center Russian National Collection of Industrial Microorganisms (BRCVKPM) \# B3300), Bifidobacterium bifidum 1 (SCPM-Obolensk \# 900791), and Bifidobacterium (BRV 37 2000).

2.2. Cultivation of Strains. Lyophilized strains of L. plantarum 8 RA 3, L. fermentum 90 TC 4, and L. fermentum 39 were grown according to the method described previously [12], using liquid and agarized MRS nutrient medium (Syntex, Russia). Recovery and inoculation of strains of $B$. bifidum 1, B. bifidum 791, and B. longum 379 were carried out according to a similar scheme using the HMM liquid medium (hydrolyzate-milk medium, Syntex, Russia) and Bifidobacterium agar medium (HiMedia, India). We used cell suspensions of the third generation of each culture grown using the liquid media-MRS for lactic acid bacillus and HMM for bifidobacteria containing $10^{8}$ cells $/ \mathrm{ml}$. Each suspension was centrifuged for $10 \mathrm{~min}$ at $3000 \mathrm{~g}$. To study antiviral activity, we used liquid media, supernatant fluid, and bacteria after centrifugation of $1 \mathrm{ml}$ suspension.

2.3. Identification of Strains. Grown colonies of microorganisms were identified using the Bruker Daltonics Autoflex
MALDI TOF mass spectrometer (Germany). The sample preparation was performed by direct application according to the standard protocol presented in the user manual. The mass spectra identification, recording, processing, and analysis were carried out using the BioTyper hardware-software complex.

2.4. Biochemical Property Study. The biochemical properties of the strains were confirmed using the BioMerieux API 50 CHL and API 20 A (France) test systems.

2.5. Whole Genome Sequencing. To conduct whole genome sequencing of the strains, genomic DNA was isolated using the QIAamp DNA Mini Kit QIAGEN commercial kit (Germany), and fragmentation was performed using the Applied Biosystems Covaris E210 ultrasonic fragmentation (USA) according to the manufacturer's instructions. The mixture purification and the 200-700 bp fragments selection were carried out using the Beckman Coulter Agencourt AMPure beads magnetic particles (USA) and New England Biolabs NEBNext Sizing Buffer (USA). Libraries were prepared using the Illumina Inc. TrueSeq kit (USA), and the sequencing was performed on the Illumina Inc. MiSeq platform (USA). The source reads were processed by Trimmomatic with standard parameters for Illumina. Then, the processed reads were used to assemble the de novo genome using the Spades, MIRA 4.0, and Newbler 2.6 programs.

2.6. Genome Annotation. Genome annotations were performed using the Prokka v. 1.11 utility [13] and the RAST genomic server (http://rast.nmpdr.org). The determinants of antibiotic resistance and pathogenicity were searched using software products available on the website of the Center for Genomic Epidemiology (http://www.cge.cbs.dtu.dk/): ResFinder 2.0, PathogenFinder, and PlasmidFinder programs [14-16].

2.7. The Determination of Probiotic Cytotoxicity for MDCK and VERO E6 Cells. The toxicity of all cell suspensions and the supernatant obtained from $1 \mathrm{ml}$ of cell suspension, as well as microbiological media that were used to grow probiotic bacteria, were studied using the MTT test. Various bacterial concentrations were added, as well as the medium in which the bacteria were grown (supernatant from centrifugation of $1 \mathrm{ml}$ of cell suspension) into 96-well plates (Greiner BioOne) with MDCK cells (dog kidney cells). Cells were cultured for 72 hours, and cell viability was monitored by the MTT test (methylthiazolyldiphenyltetrazolium bromide) [17].

2.8. Antiviral Activity against Influenza A Virus Study. For antiviral activity analysis in vitro, the wells of a 96-well plate were inoculated with MDCK cell culture in MDCK DMEM (Gibco) medium supplemented with 5\% bovine serum (Gibco) and antibiotics. The inoculating dose was $2 \times 10^{4}$ cells per well. After the $90 \%$ monolayer formation (20 hours of incubation at $37^{\circ} \mathrm{C}$ in an atmosphere of $5 \% \mathrm{CO}_{2}$ ), the cells were washed with serum-free medium. In a serological 96well plate, twofold dilutions of the studied substances were prepared on a growth culture medium (DMEM Gibco, antibiotics, TRSC-trypsin $2 \mu \mathrm{g} / \mathrm{ml}, 0.2 \%$ of bovine albumin) in a 
volume of $100 \mu \mathrm{l} .100 \mu \mathrm{l}$ of the virus at a dose of $100 \mathrm{TCID}_{50}$ was added to each well. The influenza A/Lipetsk/1V/2018 (H1N1 pdm09) (EPI_ISL_332798) and A/common gull/Saratov/1676/2018 (H5N6) (EPI_ISL_336925) virus strains were used in this work. The suspension was held for $60 \mathrm{~min}$ at a temperature of $37^{\circ} \mathrm{C}$ and introduced into the culture plate wells with MDCK cells. The MDCK cells were incubated at $37^{\circ} \mathrm{C}$ in an atmosphere of $5 \% \mathrm{CO}_{2}$ for $72 \mathrm{~h}$. Then, a neutral red was added to each well (final concentration $-0.34 \%$ ), cells were washed after $1.5 \mathrm{~h}$, a dye extraction solution was added $\left(0.1 \mathrm{M} \mathrm{NH}_{4} \mathrm{H}_{2} \mathrm{PO}_{4}\right.$ and $96 \%$ ethanol in equal volumes), and the optical density of the released dye was determined on the BioRad 680 microplate reader at a wavelength of 490 nm using the Zemfira 2.0 software.

2.9. Antiviral Activity against SARS-CoV-2 Study. The antiviral activity was investigated against the SARS-CoV-2 virus of Australia/VIC01/2020 strain (GenBank: MT007544.1), kindly provided by the Western Pacific Office of the World Health Organization. A culture of Vero E6 cells (grass monkey kidney cells) was added to the wells of a 96-well plate in Needle MEM medium (Gibco) supplemented with 5\% bovine serum (Gibco) and antibiotics. The inoculating dose is $1.5 \times 10^{4}$ cells per well. After the $90-100 \%$ monolayer formation ( 48 hours of incubation at $37^{\circ} \mathrm{C}$ in an atmosphere of $5 \% \mathrm{CO}_{2}$ ), the cells were washed with serum-free medium. The supernatant suspension or probiotic bacteria were diluted from $1: 2$ to $1: 128$ and introduced into the culture plate wells with Vero E6 cells. Cells were incubated for $2 \mathrm{~h}$ at $37^{\circ} \mathrm{C}$ and $5 \% \mathrm{CO}_{2}$, after which $100 \mu \mathrm{l}$ of the virus was added at a dose of 0.1 TCID50/cell and incubated for 3 days at $37^{\circ} \mathrm{C}$ and $5 \% \mathrm{CO}_{2}$. The results were determined using the MTT test, as described above, and the results were processed using the SOFTmaxPro 4.0 program (USA). The $\chi 2$ test was used to determine the statistical significance of differences in cell viability. The calculation was carried out using the statistical software package Statistica 6.0. A $p$ value $<0.05$ was considered significant.

\section{Results}

At the first stage of the work, phenotypic characteristics of strains were studied by studying their biochemical properties and protein mass spectra in order to select cultures intended for further studies of their entire genome. Then, whole genome sequencing of strains was performed, and the obtained nucleotide readings (reads) were used to assemble de novo genomes using modern bioinformatic programs. Genomes collected in the contigs format are registered in the GenBank/EMBL/DDBJ international database. The main genome characteristics of the studied strains are presented in Table 1 .

3.1. Analysis of the Determinants of Pathogenicity and Antibiotic Resistance. According to the results, all investigated strains are not pathogenic for humans, and determinants of antibiotic resistance and integrated plasmids were not found in their genomes. Molecular efflux pumps of the MatE and MFS families were found in all Lactobacillus, which cause bacterial resistance to gentamicin, cefotaxime, tetracycline, ciprofloxacin, furazolidone, vancomycin, and sulfonamides (Table 1).

All Bifidobacterium have molecular efflux pumps of the MatE family, which cause the resistance of microorganisms to ampicillin, tetracycline, erythromycin, gentamicin, cefepime, cefotaxime, ciprofloxacin, furazolidone, polymyxin, and sulfamanidamicin. In addition, the cytoplasmic protein tetW was found in B. longum 379, which protects the ribosome from the effects of tetracycline (Table 1). No genes responsible for the synthesis of bacteriocins were identified.

3.2. Analysis of the Determinants of Sugar Metabolism. Genomic determinants of sugar metabolism were analyzed using the RAST server (http://www.nmpdr.org/). It was found that the subsystem of sugar metabolism in L. plantarum 8 RA 3 consists of 426 determinants. Due to the fact that this microorganism has a facultatively heteroenzymatic type of metabolism, its genome contains determinants of two pathways of sugar metabolism, fructose bisphosphate, and pentose phosphate, which allow the fermentation of sugars with the formation of acetic and lactic acids, formate, and ethanol. Determinants of the metabolism of monosaccharides were found in the genome: mannose, ribose, rhamnose, sorbose, arabinose, etc., di- and oligosaccharides, fructooligosaccharides and raffinose, amino sugars-chitin, $\mathrm{N}$-acetylglucosamine, and glycogen (Table 1).

In the L. fermentum 90 TC 4 strain, this subsystem is represented by 113 determinants. The strain belongs to obligate heteroenzymatic group $\mathrm{C}$ lactobacilli; therefore, its genome lacks the main enzymes of the fructose bisphosphate pathway, aldolase, and triose phosphate-isomerase. However, the determinants of the pentose phosphate pathway are presented, which is the main variant of carbohydrate metabolism and allows fermentation of the sugar with the formation of lactic acid. The strain is distinguished by the "poor" spectrum of utilized sugars; it is unable to ferment mannose, ribose, and arabinose, which is due to the absence of individual genes ( $\mathrm{RbsD}$ permease, phosphotransferase system (PTS ScrA), or whole operons (arabinose operon)) (Table 1).

The sugar metabolism subsystem of L. fermentum 39 strain consists of 118 determinants. This strain also belongs to the group of heterofermentative lactobacilli of group C. Aldolase and triose phosphate-isomerase are absent in the genome, but the determinants of the pentose phosphate pathway are presented, which allows the fermentation of sugars to form lactic, acetic acids, and $\mathrm{CO}_{2}$. In the genome, the operons of metabolism and transport of mono- and disaccharides, riboflavin, and glycerol, which are absent in L. fermentum 90 TC 4, are determined (Table 1).

It has been established that the fructose-6-phosphate phosphoketolase pathway is the main pathway of carbohydrate metabolism in all studied Bifidobacterium. The products are lactic acid, acetic acid, and ethanol. The subsystems of sugar metabolism in B. longum 379, B. bifidum 1, and $B$. bifidum 791 consist of 199, 175, and 207 determinants, respectively. The genome of B. longum 379 contains determinants responsible for the utilization of monosaccharides 
TABLE 1: The main genome characteristics of the studied probiotic bacteria.

\begin{tabular}{|c|c|c|c|c|c|}
\hline Bacteria & $\begin{array}{l}\text { Main characteristics of } \\
\text { the genome }\end{array}$ & $\begin{array}{c}\text { Determinants of } \\
\text { bacteriocin } \\
\text { synthesis }\end{array}$ & $\begin{array}{l}\text { Determinants of } \\
\text { antibiotic resistance }\end{array}$ & $\begin{array}{l}\text { Determinants of sugar } \\
\text { metabolism }\end{array}$ & $\begin{array}{c}\text { Determinants of } \\
\text { exopolysaccharide } \\
\text { synthesis }\end{array}$ \\
\hline L. plantarum 8 RA 3 & $\begin{array}{c}\text { GenBank number } \\
\text { LBDF00000000 } \\
\text { Genome type draft } \\
\text { Number of contigs } 18 \\
\text { Genome size 3,330,093 bp } \\
\text { Average coverage } 250.0 \\
\text { GC composition } 44.4 \% \\
\text { CDS quantity } 2982\end{array}$ & $\begin{array}{l}\text { KLD40925.1, } \\
\text { KLD40929.1, } \\
\text { KLD40930.1, } \\
\text { KLD40931.1, } \\
\text { KLD40932.1, } \\
\text { KLD40933.1 } \\
\text { Contig } 4 \\
\text { LBDF01000008.1 }\end{array}$ & $\begin{array}{l}\text { Efflux pumps } \\
\text { MatE } \\
\text { KLD43042.1 } \\
\text { MFS } \\
\text { KLD43077.1 }\end{array}$ & $\begin{array}{c}426 \text { determinants } \\
\text { Fructose bisphosphate pathway } \\
\text { Pentose phosphate pathway } \\
\text { Utilization of } \\
\text { fructooligosaccharides and } \\
\text { raffinose: Msm KLD40778.1, } \\
\text { PTS KLD43366.1, KLD43367.1, } \\
\text { KLD43368.1, SacA } \\
\text { KLD43120.1, DexB } \\
\text { KLD43365.1, Aga KLD42863.1, } \\
\text { Man KLD43356.1 и BG } \\
\text { KLD41117.1 } \\
\text { Utilization of amino sugars: } \\
\text { NagA KLD43035.1, NagB } \\
\text { KLD43152.1, PTS NagT } \\
\text { KLD42190.1, NagR } \\
\text { KLD40894.1, Cbp KLD42577.1 } \\
\text { ChiA KLD43348.1 } \\
\text { Glycogen metabolism: GAT } \\
\text { KLD43421.1, GS KLD43423.1, } \\
\text { GP KLD43424.1 }\end{array}$ & $\begin{array}{c}\text { Eps operon } \\
\text { EpsB KLD41507.1 } \\
\text { EpsC KLD40740.1 } \\
\text { EpsD KLD40739.1 } \\
\text { EpsE KLD41508.1 } \\
\text { EpsF KLD41509.1 } \\
\text { Contig } 15 \\
\text { LBDF01000011.1 }\end{array}$ \\
\hline $\begin{array}{l}\text { L. fermentum } 90 \\
\text { TC-4 }\end{array}$ & $\begin{array}{c}\text { GenBank number } \\
\text { LBDH00000000 } \\
\text { Genome type draft } \\
\text { Number of contigs } 93 \\
\text { Genome size } 1,822,484 \mathrm{bp} \\
\text { Average coverage } 250.0 \\
\text { GC composition } 51.9 \% \\
\text { CDS } 1620 \text { quantity }\end{array}$ & & $\begin{array}{c}\text { Efflux pumps } \\
\text { MatE } \\
\text { KLD54124.1 } \\
\text { MFS } \\
\text { KLD53990.1 }\end{array}$ & $\begin{array}{c}113 \text { determinants } \\
\text { Pentose phosphate } \\
\text { Pathway utilization of } \\
\text { disaccharides: GalK } \\
\text { KLD53103.1, FruK } \\
\text { KLD55067.1, } \alpha \text {-Gal } \\
\text { KLD53100.1, } \beta \text {-Gal WP_ } \\
\text { 046949162.1, mapA } \\
\text { P_046948545.1, } \beta \text {-glucosidase } \\
\text { KLD43584.1 }\end{array}$ & $\begin{array}{c}\text { Eps operon } \\
\text { EpsB KLD49590.1 } \\
\text { EpsC KLD49588.1 } \\
\text { EpsD KLD49589.1 } \\
\text { Contig 15 } \\
\text { LBDH01000061.1 }\end{array}$ \\
\hline L. fermentum 39 & $\begin{array}{c}\text { GenBank number } \\
\text { LBDG00000000 } \\
\text { Genome type draft } \\
\text { Number of contigs } 55 \\
\text { Genome size } 1,829,655 \mathrm{bp} \\
\text { Average coverage } 250.0 \\
\text { GC composition } 51.6 \% \\
\text { CDS quantity } 1683\end{array}$ & & $\begin{array}{l}\text { Efflux pump } \\
\text { MatE } \\
\text { KLD56150.1 }\end{array}$ & $\begin{array}{c}118 \text { determinants } \\
\text { Pentose phosphate metabolic } \\
\text { pathway } \\
\text { Utilization of arabinose: AraR } \\
\text { KLD56054.1, AraK } \\
\text { KLD56053.1, AraA } \\
\text { KLD56052.1, AraD } \\
\text { KLD56052.1, AraT } \\
\text { KLD56053.1 } \\
\text { Glycerol utilization: GlpT } \\
\text { KLD54015.1, GlpF } \\
\text { KLD56071.1, GlpK } \\
\text { KLD55877.1, GPD } \\
\text { KLD55407.1 } \\
\text { Riboflavin metabolism: RybD } \\
\text { KLD54636.1, RSA KLD54605.1 }\end{array}$ & $\begin{array}{c}\text { Eps operon } \\
\text { EpsB KLD51897.1 } \\
\text { EpsC KLD51899.1 } \\
\text { EpsD KLD51898.1 } \\
\text { EpsE KLD51903.1 } \\
\text { Contig 20 } \\
\text { LBDG01000035.1 }\end{array}$ \\
\hline
\end{tabular}


TABLE 1: Continued.

\begin{tabular}{|c|c|c|c|c|c|}
\hline Bacteria & $\begin{array}{l}\text { Main characteristics of } \\
\text { the genome }\end{array}$ & $\begin{array}{l}\text { Determinants of } \\
\text { bacteriocin } \\
\text { synthesis }\end{array}$ & $\begin{array}{c}\text { Determinants of } \\
\text { antibiotic resistance }\end{array}$ & $\begin{array}{c}\text { Determinants of sugar } \\
\text { metabolism }\end{array}$ & $\begin{array}{c}\text { Determinants of } \\
\text { exopolysaccharide } \\
\text { synthesis }\end{array}$ \\
\hline B. longum 379 & $\begin{array}{c}\text { GenBank number } \\
\text { LKUQ00000000 } \\
\text { Genome type draft } \\
\text { Number of contigs } 24 \\
\text { Genome size } 2,387,620 \mathrm{bp} \\
\text { Average coverage } 150.0 \\
\text { GC composition } 60.2 \% \\
\text { CDS } 1903 \text { quantity }\end{array}$ & & $\begin{array}{c}\text { Efflux pump } \\
\text { MatE } \\
\text { КҮЈ82530.1 } \\
\text { цитоплазматический } \\
\text { белок } t e t W \\
\text { КҮЈ81078.1 }\end{array}$ & $\begin{array}{c}199 \text { determinants } \\
\text { Fructose-6-phosphate } \\
\text { phosphoketolase pathway } \\
\text { Amino sugar metabolism: } \\
\text { NagK KYJ78240.1, NagA } \\
\text { KYJ78237.1, NagB KYJ78238.1, } \\
\text { NagT KYJ81992.1, NagR } \\
\text { KYJ82080.1 } \\
\text { Glycogen metabolism: GAT } \\
\text { KYJ81114.1, GS KYJ81082.1, } \\
\text { GBr KYJ82453.1, GP } \\
\text { KYJ83271.1, GdBr KYJ82081.1, } \\
\text { AMse KYJ82084.1, MalE } \\
\text { KYJ78457.1 } \\
\text { Utilization of raffinose and } \\
\text { fructooligosaccharides: MsmR } \\
\text { KYJ82093.1, MsmE } \\
\text { KYJ82142.1, MsmF } \\
\text { KYJ82092.1, MsmG, } \\
\text { KYJ82141.1, SacA KYJ78008.1, } \\
\text { Aga KYJ83465.1 }\end{array}$ & $\begin{array}{c}\text { Genes for } \\
\text { rhamnose } \\
\text { synthesis, contig } 5 \\
\text { LKUQ01000020.1 } \\
\text { Capsular } \\
\text { polysaccharide } \\
\text { genes: Wzb } \\
\text { KYJ83195.1, Wzc } \\
\text { KYJ83223.1 } \\
\text { Sortase dependent } \\
\text { pili: SrtA } \\
\text { KYJ83477, AP } \\
\text { KYJ83476.1 } \\
\text { Lipoproteins: Lgt } \\
\text { KYJ83617.1, LspA } \\
\text { KYJ77995.1 }\end{array}$ \\
\hline B. bifidum 1 & $\begin{array}{c}\text { GenBank NDXI00000000 } \\
\text { Genome type draft } \\
\text { Number of contigs } 13 \\
\text { Genome size } 2,198,027 \text { bp } \\
\text { Average coverage } 385.0 \\
\text { GC composition } 62.7 \% \\
\text { CDS } 1521 \text { quantity }\end{array}$ & & $\begin{array}{c}\text { Efflux pump } \\
\text { MatE } \\
\text { PDH98462.1 }\end{array}$ & $\begin{array}{c}175 \text { determinants } \\
\text { Fructose-6-phosphate } \\
\text { phosphoketolase pathway } \\
\text { Amino sugar metabolism: } \\
\text { NagK PDH98478.1, NagA } \\
\text { PDH97531.1, NagB } \\
\text { PDH98129.1, NagT } \\
\text { PDH97280.1, CbsA } \\
\text { PDH98222.1, Aga PDH97428.1 }\end{array}$ & $\begin{array}{c}\text { Sortase dependent } \\
\text { pili: SrtA } \\
\text { PDH97100.1, } \\
\text { PDH97310.1 } \\
\text { Lipoproteins: Lgt } \\
\text { PDH98440.1, } \\
\text { LspA PDH98074.1 }\end{array}$ \\
\hline B. bifidum 791 & $\begin{array}{c}\text { GenBank number } \\
\text { LKUR00000000 } \\
\text { Genome type draft } \\
\text { Number of contigs } 33 \\
\text { Genome size } 2,285,457 \mathrm{bp} \\
\text { Average coverage } 150.0 \\
\text { GC composition } 62.4 \% \\
\text { CDS } 1769 \text { quantity }\end{array}$ & & $\begin{array}{c}\text { Efflux pumps } \\
\text { MatE } \\
\text { KYJ84349.1, } \\
\text { KYJ84414.1 }\end{array}$ & $\begin{array}{c}207 \text { determinants } \\
\text { Fructose-6-phosphate } \\
\text { phosphoketolase pathway } \\
\text { Amino sugar metabolism: } \\
\text { NagK KYJ84330, NagA } \\
\text { KYJ85076.1, NagB KYJ85077.1, } \\
\text { NagT KYJ85215.1, KYJ85216.1, } \\
\text { NagR KYJ85078.1, CbsA } \\
\text { KYJ83728.1, Aga KYJ84485.1 } \\
\text { Glycogen metabolism: GAT } \\
\text { KYJ83153.1, GS KYJ84446.1, } \\
\text { GBr KYJ84933.1, GP } \\
\text { KYJ84691.1, GdBr KYJ85154.1, } \\
\text { AMse KYJ84544.1 }\end{array}$ & $\begin{array}{c}\text { Genes for the } \\
\text { synthesis of } \\
\text { rhamnose, contig } 3 \\
\text { LKUR01000023.1 } \\
\text { Sortase dependent } \\
\text { pili: SrtA } \\
\text { KYJ84870.1, AP } \\
\text { KYJ84871.1 } \\
\text { Lipoproteins: Lgt } \\
\text { KYJ84380.1, LspA } \\
\text { KYJ85145.1 }\end{array}$ \\
\hline
\end{tabular}

(xylose, ribose, arabinose), disaccharides (sucrose, maltose, lactose, raffinose, phosphooligosaccharides), amino sugars, and glycogen. B. bifidum 1 and B. bifidum 791 have a low ability to metabolize monosaccharides; however, they are active against di-, oligosaccharides, and amino sugars-chitin, and N-acetylglucosamine. In addition, B. bifidum 791 is able to metabolize glycogen (Table 1).

3.3. Determinants of Exopolysaccharide Synthesis. It was found that the genome of all Lactobacillus contains the Eps operon responsible for the synthesis of exopolysaccharides, consisting of the enzymes EpsB (magnesium-dependent protein tyrosine phosphatase), EpsC (transmembrane tyrosine kinase), EpsD (tyrosine kinase), EpsE (galactophosphate), and polysaccharide transferase (Table 1). Analysis of this cluster suggested that all studied bacteria are capable of producing heteropolysaccharides consisting of a repeating unit of glucose and galactose.

Determinants of exopolysaccharide synthesis were found in the genome of B. longum strain 379: genes for rhamnose synthesis and genes responsible for the formation of sortase-dependent pili and cell wall lipoproteins. In the $B$. bifidum 1 strain, genes for the synthesis of exopolysaccharides were not found; however, there are determinants responsible for the formation of sortase-dependent pili and lipoproteins. The genome of B. bifidum 791 also contains 


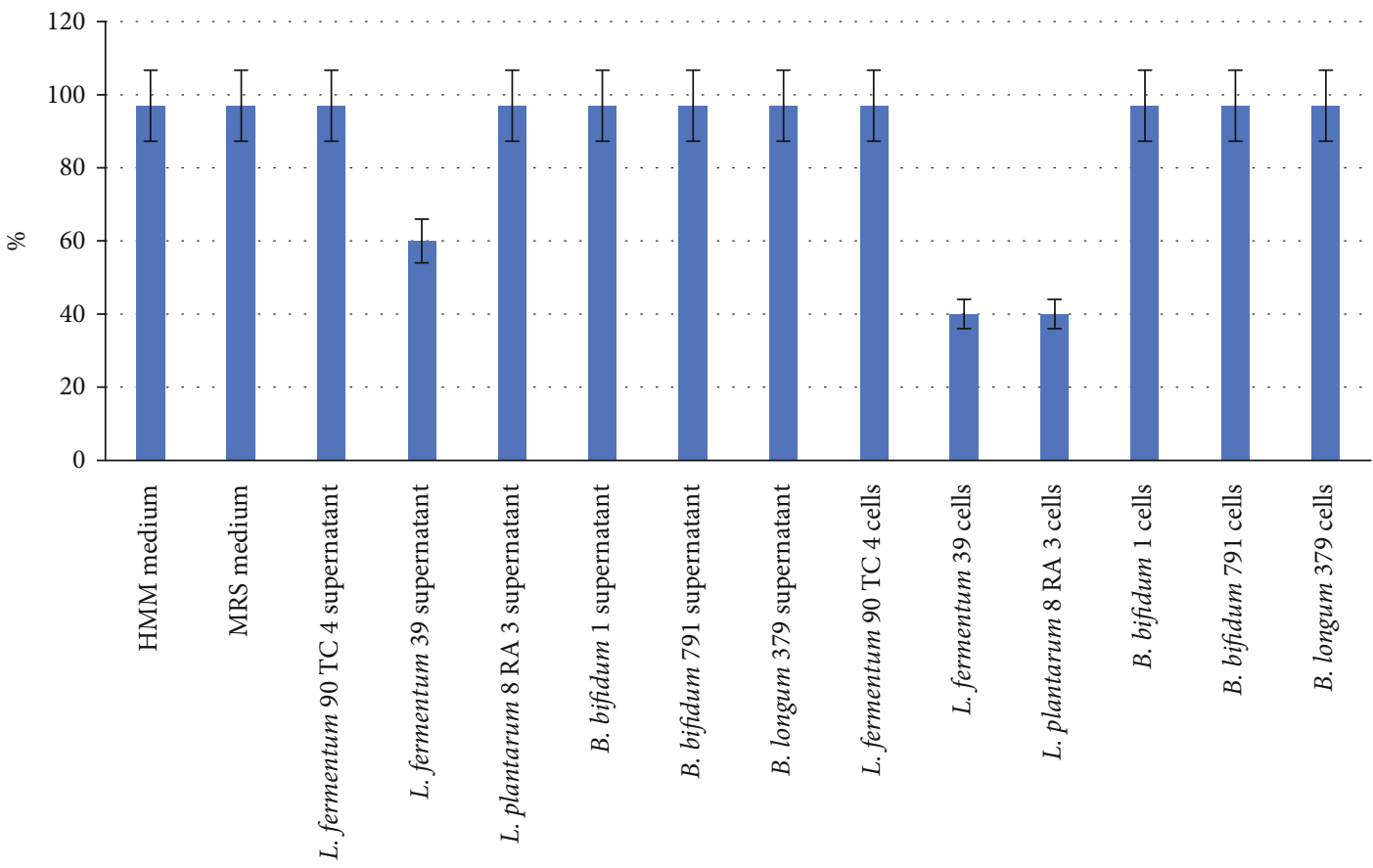

FIgURE 1: The number (in \%) of viable MDCK cells after culturing for 72 hours with investigated components of probiotic bacteria liquid cultures. The results are average values \pm standard deviations from three independent experiments. $p<0.05$.

genes for the synthesis of exopolysaccharides, including genes for the synthesis of rhamnose and genes of sortasedependent pili and cell wall lipoproteins.

Thus, it was found that the studied bacteria are nonpathogenic for humans and do not contain transmissibletype antibiotic resistance genes and integrated plasmids. Resistance to antibiotics of various classes is explained by the presence of molecular efflux pumps of the MatE family and the protective ribosomal protein TetW. The studied Lactobacillus is capable of synthesizing acetic and lactic acid, formate, ethanol, one of the types of bacteriocins from the plantaricin group (L. plantarum 8 RA 3), and extracellular polysaccharides. All Bifidobacterium are able to utilize amino sugar and glycogen, di- and oligosaccharides, and acetic and lactic acids. Determinants responsible for the formation of sortase-dependent pili and cell wall lipoproteins were found in the genomes of all Bifidobacterium. B. longum 379, in contrast to B. bifidum 791 and B. bifidum 1, is able to utilize monosaccharides (xylose, ribose, arabinose). B. longum 379 and B. bifidum 791 contain determinants of exopolysaccharide synthesis, which are absent in B. bifidum 1 .

3.4. The Toxicity Bacteria Suspensions and Culture Fluid. The toxicity of all bacteria suspensions and the supernatant obtained from $1 \mathrm{ml}$ of bacteria suspension, as well as microbiological media that were used to grow probiotic bacteria, were studied in the MTT test. The results are presented in Figure 1.

As can be seen, the L. fermentum 39 and L. plantarum 8 RA 3 cell suspensions, as well as the supernatant obtained from the L. fermentum 39 cell suspension centrifugation, were toxic to MDCK cells. The remaining components studied in this work were nontoxic to mammalian cells.
3.5. The Antiviral Activity against Influenza A Virus Study. The antiviral activity study results are presented in Figure 2.

As can be seen from the data in Figure 2, the HMM medium did not have antiviral activity, in contrast to the MRS medium, which moderately inhibited the influenza virus reproduction. The supernatant obtained by centrifuging $1 \mathrm{ml}$ of $L$. fermentum 90 TC 4 culture and the supernatant of B. bifidum 791 culture showed pronounced activity against the epidemic influenza A/Lipetsk/1V/2018 virus (H1N1 pdm09). They were active up until a dilution to $12.5 \%$ of the initial suspension. The cells of these bacterial cultures suppressed the influenza virus epidemic strain reproduction before diluting the suspension of bacterial cells to $6.25 \%$ of the initial suspension. The L. plantarum 8 RA 3 bacteria reduced the virus reproduction by $50 \%$ upon cell suspension dilution to $12.5 \%$ of the initial suspension. Supernatants and B. bifidum 1 and B. longum 379 cells showed a decrease in the virus cytopathic effect on MDCK cells at the same level as the medium in which these bacteria were grown.

The supernatants of L. plantarum 8 RA 3 and B. bifidum 791 bacterial cultures showed activity against the highly pathogenic avian influenza A/chicken/Nghe $\mathrm{An} / 27 \mathrm{VTC} / 2018$ (H5N6) strain until dilution to $12.5 \%$ of the initial concentration. The virus reproduction was reduced by $50 \%$ with L. fermentum 90 TC 4 and L. fermentum 39 cell suspension at a concentration of $3.13 \%$ of the initial suspension and B. bifidum 791 cell suspension at a concentration of $6.25 \%$ of the initial one.

Thus, the Lactobacillus fermentum bacteria of 90 TC 4 strain, Lactobacillus fermentum of 39 strain, and Bifidobacterium bifidum of 791 strain appeared to be the most promising cultures for further antiviral activity studies. They were further investigated. The results are presented in Figure 3. 


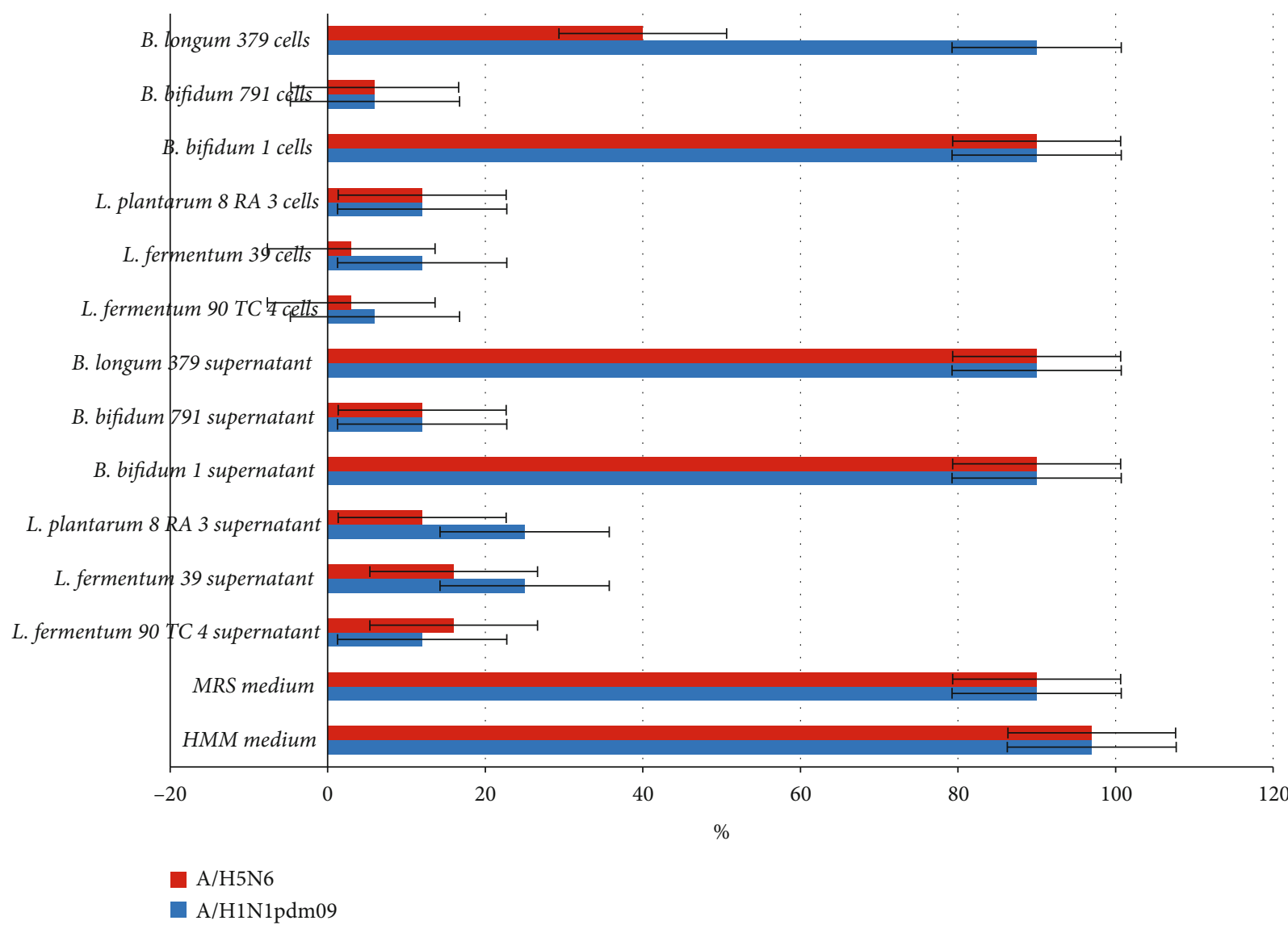

FIGURE 2: The smallest amount (in \% of the initial suspension of bacteria or culture medium) that protects $50 \%$ of MDCK cells after infection with influenza viruses. Red color indicates the A/Lipetsk/1V/2018 (H1N1 pdm09) virus infection; blue color indicates the A/common gull/Saratov/1676/2018 (H5N6) virus infection. The results are average values \pm standard deviations from three independent experiments. $p<0.05$.

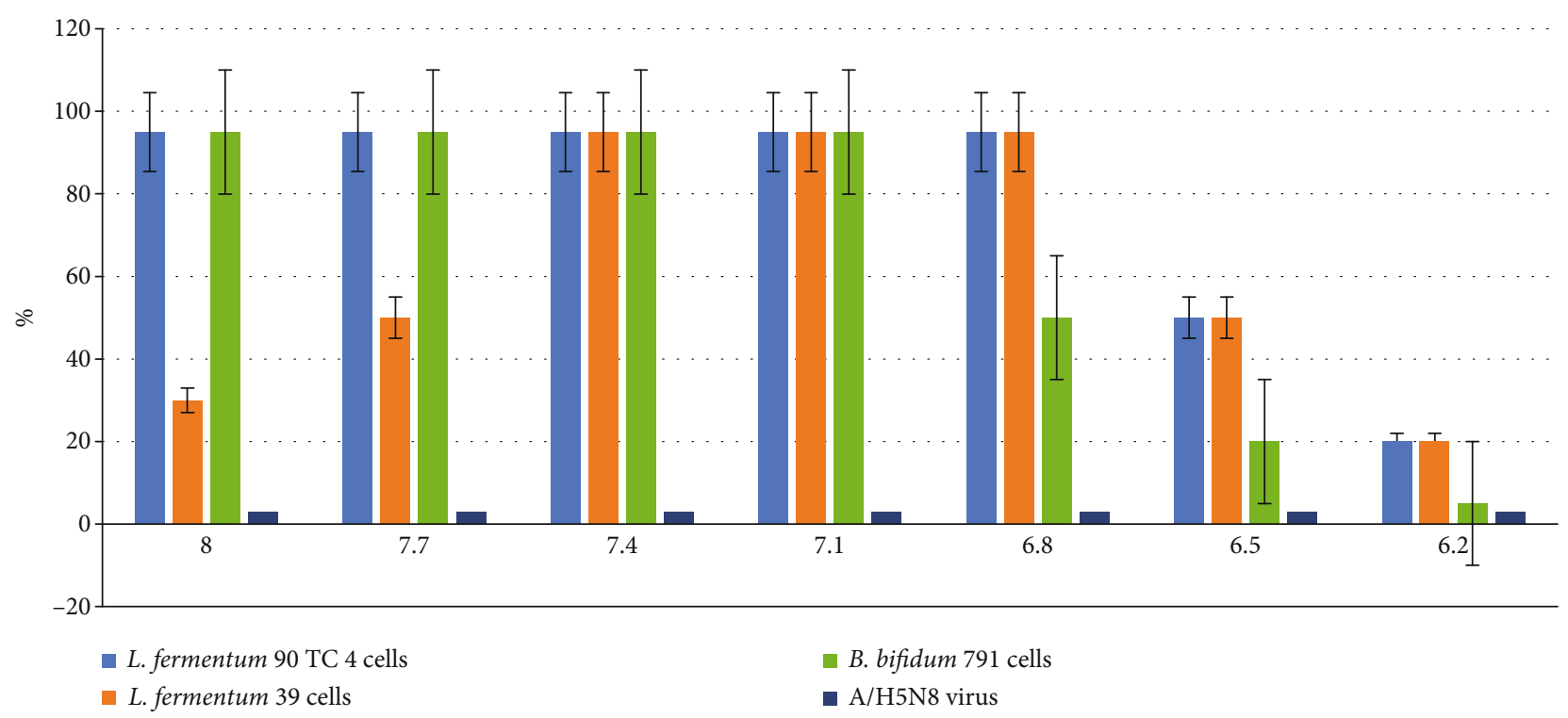

FIgURE 3: The number (in \%) of viable MDCK cells after virus infection at a dose of $100 \mathrm{TCID} /{ }_{50}$ and during incubation with different concentrations of bacteria. Along the abscissa axis is the logarithm of bacteria concentration, and along the ordinate axis is the \% of viable cells. A positive control (uninfected cells were cultured without probiotic bacteria) is $100 \%$ viable cells. The results are average values \pm standard deviations from three independent experiments. $p<0.05$. 


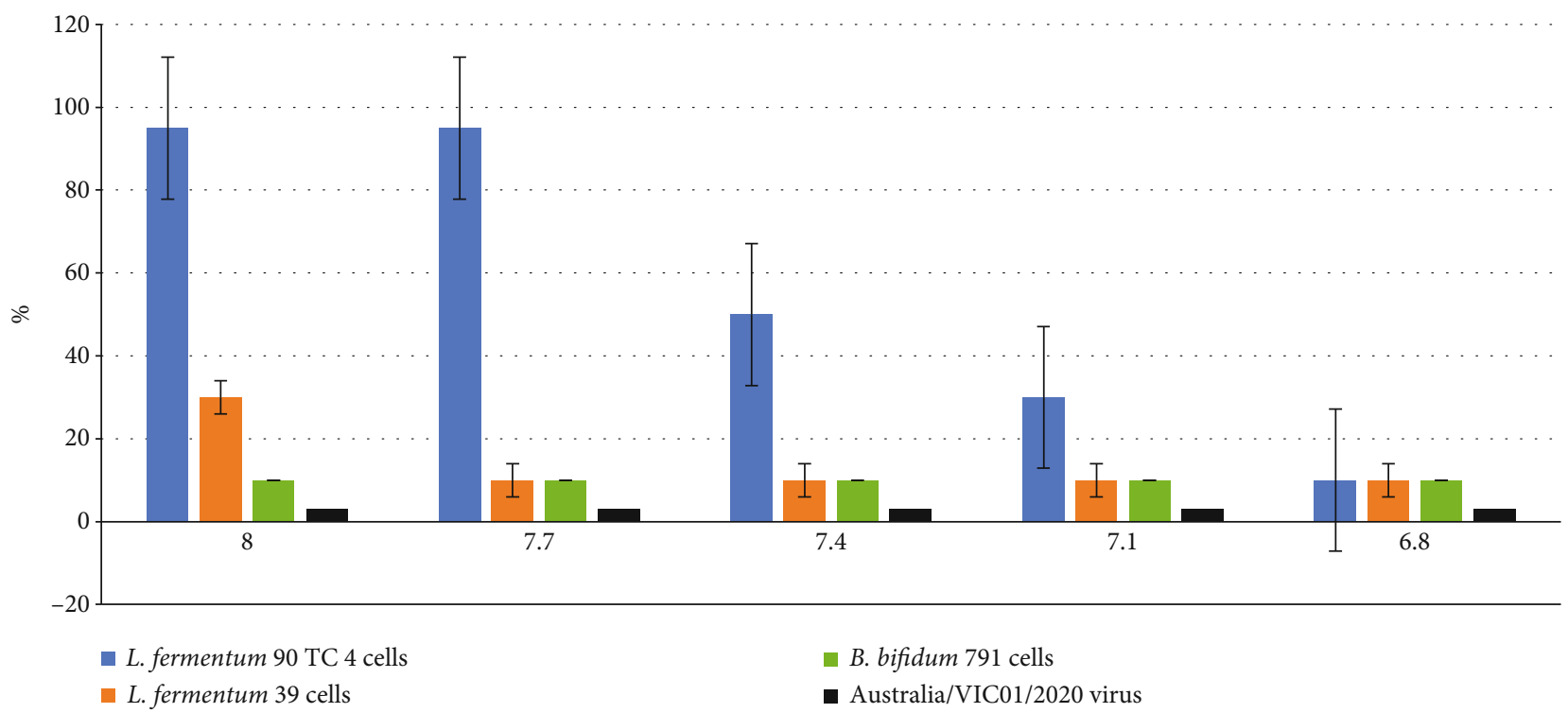

Figure 4: The number (in \%) of viable VERO E6 cells after virus infection at a dose of $100 \mathrm{TCID} / 50$ and during incubation with different concentrations of bacteria. Along the abscissa axis is the logarithm of bacteria concentration, and along the ordinate axis is the $\%$ of viable cells. A positive control (uninfected cells were cultured without probiotic bacteria) is $100 \%$ viable cells. The results are average values \pm standard deviations from three independent experiments. $p<0.05$.

As can be seen in Figure 3, all three cultures of probiotic bacteria showed pronounced antiviral activity against the highly pathogenic strain of the influenza A/common gull/Saratov/1676/2018 (H5N6) virus to a concentration of $10^{7.1}$, and the Lactobacillus fermentum of 90 TC 4 strain and Lactobacillus fermentum of 39 strain bacterial suspension to a concentration of $10^{6.8}$ completely suppressed the multiplication of influenza virus in MDCK cells.

3.6. The Antiviral Activity against SARS-CoV-2 Study. The antiviral activity against SARS-CoV-2 was studied on VERO E6 cells according to a scheme, described in Materials and Methods. The results are presented in Figure 4.

As can be seen from the data in Figure 4, only L. fermentum 90 TC 4 cells produced an antiviral effect against the SARS-CoV-2 virus. Nevertheless, in our opinion, these are encouraging results that allow us to recommend the probiotic bacteria for COVID-19 prevention.

\section{Discussion}

During the influenza pandemic and sometimes during seasonal epidemics, gastrointestinal manifestations of the disease are observed, especially in children. In addition, it has been shown that the highly pathogenic avian influenza virus often infects the intestinal epithelium during human infection [10].

The situation associated with the incidence of zoonotic influenza remains tense. More than 860 cases of human infection with highly pathogenic avian influenza A/H5N1 virus, with an increased incidence of children under 15 years and a mortality rate of over $50 \%$, have been registered in the world [18]. Since 2013, the carryover of A/H7N9 influenza virus from birds to humans has been confirmed in more than 1,500 cases, resulting in severe pneumonia with multiple organ failures and a mortality rate of approximately $40 \%$ (data as of January 31, 2021) [19]. If these viruses begin to be effectively carried over from person to person, they can cause an influenza pandemic with very drastic consequences.

In December 2019, an outbreak of disease caused by the SARS-CoV-2 coronavirus was recorded in Wuhan, China. In March 11, 2020, the WHO President announced the pandemic breakout [20]. As for all respiratory viruses, the site of SARS-CoV-2 entry is the upper respiratory tract epithelial cells, but it has been shown that the new coronavirus often infects the intestinal tract epithelium [11]. The angiotensin converting enzyme 2 (ACE2), which is a receptor for the SARS-CoV-2 virus [21], is presented in abundance not only in the alveolar epithelial cells of the lungs but also in enterocytes of the small intestine, in the upper esophagus, liver, and colon [22]. Moreover, it was indicated that viral RNA excretion in feces was detected longer than in swabs from the nasopharynx [23].

At the present stage, a new direction in the treatment and prevention of viral infections is associated with the use of probiotic bacteria strains of Lactobacillus and Bifidobacterium genera. Research and clinical trials are currently being conducted in the world that are devoted to them [24]. It has been shown that probiotic bacteria are capable of producing an antiviral effect by stimulating the general immune response. They increase the induction of interleukins and activation of macrophages, natural killer cells, and Thelpers and stimulate the production of immunoglobulins, in particular IgA, type I interferons [25, 26]. Several investigators considered the ability of bacteria to adhere to the virus particles as a mechanism of probiotic antiviral action. It was found that individual strains of Lactobacillus are able to adsorb the virus of vesicular stomatitis particles (Rabdoviridae family), $\mathrm{A}$ and B4 Coxsackie virus (Picornaviridae 
family), A71 enterovirus (Picornaviridae family), and human noroviruses (Caliciviridae family) [25-29]. The mechanism of bacterial cell and viral particle interaction is interpreted as physical adsorption by most investigators, which is carried out due to nonspecific Van der Waals forces and is strainspecific $[28,29]$.

Active metabolites produced by probiotic microorganisms, such as lactate, hydrogen peroxide, short-chain fatty acids, and bacteriocins, have a direct virucidal effect, as they cause a decrease in the medium $\mathrm{pH}$, a violation of the viral particle adhesion mechanism due to changes in their receptor properties [28, 30-32]. All too often, the whole complex of extracellular substances has an antiviral effect, and it is not possible to isolate a separate active substance [33]. There is also evidence that lactic acid bacilli exopolysaccharides, which are homo- or heteropolysaccharides of various chemical compositions and also having strain specificity, have a pronounced antiviral effect [34].

All probiotic strains of Lactobacillus genus in this study have a range of properties that can provide an antiviral effect-the production of organic acids, ethanol, and exopolysaccharides. The L. plantarum 8 RA 3 strain was considered promising in this regard, since it is the most metabolically active, capable of synthesizing plantaricin, and has high antagonistic activity against pathogenic and opportunistic pathogenic bacteria. However, this strain did not show high antiviral activity in the experiment with influenza A viruses, in contrast to L. fermentum 90 TC 4 and L. fermentum 39 bacteria. In addition, culture fluids (supernatants) containing only bacterial metabolites of L. fermentum 90 TC 4 and L. fermentum 39 also exhibited antiviral activity, and L. fermentum 90 TC 4 bacteria showed antiviral activity in the experiment with SARS-CoV-2.

All the studied cultures are capable of producing heteropolysaccharides, consisting of galactose and glucose residues; however, L. plantarum 8 RA 3 polysaccharides differ in spatial conformation and other characteristics from exopolysaccharides (EPS) of L. fermentum 90 TC 4 and L. fermentum 39. Perhaps, this is one of the factors causing differences in their antiviral activity, which is consistent with the data of Kim et al. [34].

As for bacteria of Bifidobacterium genus, the scientific literature describes the assumptive mechanisms of their antiviral action-a stimulation of the macroorganism immune response, a production of organic acids, ethanol, exopolysaccharides, and also cell wall secreted lipoproteins (LpAs), which are capable of obstructing the interaction of viral particles with human mucous membrane receptors and thereby preventing the infection progression [24].

According to present knowledge, the representatives of $B$. adolescentis, $B$. longum, and $B$. breve species show activity against viruses, and it has been shown that this is a strainspecific feature $[24,26,32]$. According to data obtained from experimental studies conducted in France, Korea, and Colombia in 2015-2017, the representatives of B. longum species showed pronounced antiviral activity against human entero- and rotavirus [24, 26, 32].

However, in our study, the B. longum 379 strain, despite being characterized as metabolically active, did not show activity against influenza A viruses-the epidemic A/Lipetsk/1V/2018 (H1N1) influenza virus and the highly pathogenic avian A/common gull/Saratov 1676/2018 (H5N6) influenza virus. Within the framework of this study, the antiviral activity of representatives of B. bifidum species, B. bifidum 1, and B. bifidum 791 strains was first studied. These cultures do not utilize the monosaccharides; that is, they have a less pronounced metabolic potential, and B. bifidum 1 strain is not capable of synthesizing exopolysaccharides, which probably causes absence of its antiviral activity.

Only the B. bifidum 791 strain showed a pronounced activity against influenza A viruses; moreover, the culture fluid has also a virucidal effect. This may be due to strainspecific features-structural features of the cell wall, as well as the ability to produce secreted (free) lipoproteins to the culture medium.

Thus, our data showing that probiotic bacteria inhibit the highly pathogenic respiratory virus reproduction in cell culture is important for the prevention and treatment of diseases caused by respiratory viruses that can affect the human intestinal tract. The acute relevance of this topic due to the epidemiological situation in the world makes it imperative to continue these studies.

There is a limitation of this study. Testing of antiviral activity was carried out in vitro in Madin-Darby canine kidney cells (MDCK) and green monkey kidney cells (Vero) due to their most sensitivity to influenza virus and SARS-CoV-2 virus, respectively $[35,36]$. We plan to conduct the study in animals to confirm our conclusions on the viability to use probiotics when treating respiratory viral infections. After that, we plan to lead the clinical trial. Thus, the study by Wang et al. [37] showed that probiotics are promising for treating viral pneumonia; their application decreases inflammatory reactions, induces both inherent and adaptive immune responses, and prevents consecutive bacterial infections. As bacteria demonstrated in this study are already actively used as probiotics in Russia, we plan to lead the clinical trial in hospitals where probiotics will be included in the regular treatment of patients infected with respiratory viruses including SARS-CoV-2.

\section{Data Availability}

Data are available on demand.

\section{Disclosure}

The funders had no role in the design of the study; in the collection, analyses, or interpretation of data; in the writing of the manuscript; or in the decision to publish the results. The study was conducted under the state assignment of Rospotrebnadzor no. 3/21 (SRC VB “Vector").

\section{Conflicts of Interest}

The authors declare no conflict of interest. 


\section{Authors' Contributions}

Irina V. Soloveva and Tatyana N. Ilyicheva contributed to the conceptualization. Irina V. Soloveva, Tatyana N. Ilyicheva, Vasiliy Yu. Marchenko, and Oleg V. Pyankov contributed to the methodology. Irina V. Soloveva, Tatyana N. Ilyicheva, Vasiliy Yu. Marchenko, and Oleg V. Pyankov contributed to the validation. Tatyana $\mathrm{N}$. Ilyicheva contributed to the formal analysis. Anna G. Tochilina, Irina V. Belova, Vladimir A. Zhirnov, Alexander G. Durymanov, Nikolay I. Bormotov, Maksim O. Skarnovich, Svetlana B. Molodtsova, Ekaterina I. Filippova, Alene S. Ovchinnikova, and Anastasia V Magerramova contributed to the investigation. Alexander B. Rizhikov and Rinat A. Maksyutov contributed to the data curation. Irina V. Soloveva and Tatyana N. Ilyicheva contributed to the writing-original draft preparation. Tatyana N. Ilyicheva contributed to the visualization. Irina V. Soloveva contributed to the project administration. All authors have read and agreed to the published version of the manuscript. Irina V. Soloveva and Tatyana N. Ilyicheva contributed equally to this work.

\section{References}

[1] M. P. Arena, V. Capozzi, G. Spano, and D. Fiocco, "The potential of lactic acid bacteria to colonize biotic and abiotic surfaces and the investigation of their interactions and mechanisms," Applied Microbiology and Biotechnology, vol. 101, no. 7, pp. 2641-2657, 2017.

[2] A. Abdelazez, H. Abdelmotaal, Z. T. Zhu et al., "Potential benefits of Lactobacillus plantarum as probiotic and its advantages in human health and industrial applications: a review," Advances in Environmental Biology, vol. 12, no. 1, pp. 16-27, 2018.

[3] R. Clancy, "Immunobiotics and the probiotic evolution," FEMS Immunology and Medical Microbiology, vol. 38, no. 1, pp. 9-12, 2003.

[4] A. Ljungh and T. Wanstrom, Eds., Lactobacillus, molecular biology. From genomics to probiotics, Caister Academic Press, Norfolk, UK, 2009.

[5] B. Mayo and D. Sinderenvan, Eds., Bifidobacteria: genomics and molecular aspects, Caister Academic Press, Norfolk, UK, 2010.

[6] B. Henderson and L. Nibali, Eds., The human microbiota and chronic disease: dysbiosis as a cause of human pathology, John Wiley \& Sons, Hoboken, New-Jersey, 2016.

[7] I. Al Kassaa, D. Hober, M. Hamze, N. E. Chihib, and D. Drider, "Antiviral potential of lactic acid bacteria and their bacteriocins," Probiotics Antimicrob Proteins, vol. 6, no. 3-4, pp. 177185, 2014.

[8] Z. Wang, W. Chai, M. Burwinkel et al., "Inhibitory influence of Enterococcus faecium on the propagation of swine influenza a virus in vitro," PLoS One, vol. 8, no. 1, article e53043, 2013.

[9] M. F. Ducatez, R. G. Webster, and R. J. Webby, “Animal influenza epidemiology," Vaccine, vol. 26, Suppl 4, pp. D67-D69, 2008.

[10] H. Zhang, H. B. Li, J. R. Lyu et al., "Specific ACE2 expression in small intestinal enterocytes may cause gastrointestinal symptoms and injury after 2019-nCoV infection," International Journal of Infectious Diseases, vol. 96, pp. 19-24, 2020.
[11] A. G. Tochilina, I. V. Belova, I. V. Solovieva, I. S. Gorlova, T. P. Ivanova, and V. A. Zhirnov, "Characteristics of biological and MOLECULAR-GENETIC properties of Lactobacillus fermentum 90 TC-4 PROBIOTIC STRAIN," Journal of Microbiology, Epidemiology and Immunobiology, no. 2, pp. 16-23, 2016.

[12] I. V. Belova, A. G. Tochilina, I. V. Solovyeva et al., "Lactobacillus fermentum 90 TC-4 taxonomic status confirmation using whole genome sequencing and MALDI TOF mass spectrum," Russian Journal of Genetics, vol. 52, no. 9, pp. 907-913, 2016.

[13] T. Seemann, "Prokka: rapid prokaryotic genome annotation," Bioinformatics, vol. 30, no. 14, pp. 2068-2069, 2014.

[14] S. Cosentino, M. Voldby Larsen, F. Møller Aarestrup, and O. Lund, "PathogenFinder - distinguishing friend from foe using bacterial whole genome sequence data," PLoS One, vol. 8, no. 10, article e77302, 2013.

[15] I. Grissa, G. Vergnaud, and C. Pourcel, "CRISPRFinder: a web tool to identify clustered regularly interspaced short palindromic repeats," Nucleic Acids Research, vol. 35, no. Web Server, pp. W52-W57, 2007.

[16] A. E. Briner and R. Barrangou, "Lactobacillus buchneri genotyping on the basis of clustered regularly interspaced short palindromic repeat (CRISPR) locus diversity," Applied and Environmental Microbiology, vol. 80, no. 3, pp. 9941001, 2014.

[17] T. Mosmann, "Rapid colorimetric assay for cellular growth and survival: application to proliferation and cytotoxicity assays," Journal of Immunological Methods, vol. 65, no. 1-2, pp. 55-63, 1983.

[18] April 2020, http://www.who.int/influenza/human_animal_ interface/H5N1_cumulative_table_archives/en/.

[19] April 2020, http://www.fao.org/ag/againfo/programmes/en/ empres/H7N9/situation_update.html.

[20] World Health Organization, WHO Director-General's opening remarks at the media briefing on COVID-19 - 11 MarchApril 2020, https://www.who.int/dg/speeches/detail/who-directorgeneral-s-opening-remarks-at-the-media-briefing-on-covid19-11-march-2020.

[21] G. Li, X. He, L. Zhang et al., "Assessing ACE2 expression patterns in lung tissues in the pathogenesis of COVID-19," Journal of Autoimmunity, vol. 112, p. 102463, 2020.

[22] W. Zhang, R. H. du, B. Li et al., "Molecular and serological investigation of 2019-nCoV infected patients: implication of multiple shedding routes," Emerging Microbes \& Infections, vol. 9, no. 1, pp. 386-389, 2020.

[23] C. Huang, Y. Wang, X. Li et al., "Clinical features of patients infected with 2019 novel coronavirus in Wuhan, China," Lancet, vol. 395, no. 10223, pp. 497-506, 2020.

[24] K. A. el Kfoury, M. B. Romond, A. Scuotto et al., "Bifidobacteria-derived lipoproteins inhibit infection with coxsackievirus B4 in vitro," International Journal of Antimicrobial Agents, vol. 50, no. 2, pp. 177-185, 2017.

[25] M. P. Arena, V. Capozzi, P. Russo, D. Drider, G. Spano, and D. Fiocco, "Immunobiosis and probiosis: antimicrobial activity of lactic acid bacteria with a focus on their antiviral and antifungal properties," Applied Microbiology and Biotechnology, vol. 102, no. 23, pp. 9949-9958, 2018.

[26] J. Y. Kang, D. K. Lee, N. J. Ha, and H. S. Shin, “Antiviral effects of Lactobacillus ruminis SPM0211 and Bifidobacterium longum SPM1205 and SPM1206 on rotavirus-infected Caco2 cells and a neonatal mouse model," Journal of Microbiology, vol. 53, no. 11, pp. 796-803, 2015. 
[27] L. Y. E. Ang, H. K. I. Too, E. L. Tan et al., "Antiviral activity of Lactobacillus reuteri Protectis against Coxsackievirus $A$ and Enterovirus 71 infection in human skeletal muscle and colon cell lines," Virology Journal, vol. 13, no. 1, pp. 111-123, 2016.

[28] T. Botić, T. Danø, H. Weingartl, and A. Cencič, "A novel eukaryotic cell culture model to study antiviral activity of potential probiotic bacteria," International Journal of Food Microbiology, vol. 115, no. 2, pp. 227-234, 2007.

[29] S. Lei, A. Ramesh, E. Twitchell et al., "High protective efficacy of probiotics and rice bran against human norovirus infection and diarrhea in gnotobiotic pigs," Frontiers in Microbiology, vol. 7, p. 1699, 2016.

[30] A. A. Sunmola, O. O. Ogbole, T. O. C. Faleye, A. Adetoye, J. A. Adeniji, and F. A. Ayeni, "Antiviral potentials of Lactobacillus plantarum, Lactobacillus amylovorus, and Enterococcus hirae against selected Enterovirus," Folia Microbiologia (Praha), vol. 64, no. 2, pp. 257-264, 2019.

[31] S. Salminen, C. Bouley, M. C. Boutron et al., "Functional food science and gastrointestinal physiology and function," The British Journal of Nutrition, vol. 80, no. S1, pp. S147-S171, 1998.

[32] N. N. Olaya Galán, J. C. Ulloa Rubiano, F. A. Velez Reyes, K. P. Fernandez Duarte, S. P. Salas Cárdenas, and M. F. Gutierrez Fernandez, "In vitro antiviral activity of Lactobacillus casei and Bifidobacterium adolescentis against rotavirus infection monitored by NSP4 protein production," Journal of Applied Microbiology, vol. 120, no. 4, pp. 1041-1051, 2016.

[33] A. Lange-Starke, A. Petereit, U. Truyen, P. G. Braun, K. Fehlhaber, and T. Albert, "Antiviral potential of selected starter cultures, bacteriocins and D, L-lactic acid," Food and Environmental Virology, vol. 6, no. 1, pp. 42-47, 2014.

[34] K. Kim, G. Lee, H. D. Thanh et al., "Exopolysaccharide from Lactobacillus plantarum LRCC5310 offers protection against rotavirus-induced diarrhea and regulates inflammatory response," Journal of Dairy Science, vol. 101, no. 7, pp. 57025712, 2018.

[35] I. Hamamoto, H. Takaku, M. Tashiro, and N. Yamamoto, "High yield production of influenza virus in Madin Darby canine kidney (MDCK) cells with stable knockdown of IRF7," PLoS One, vol. 8, no. 3, article e59892, 2013.

[36] R. B. Rosa, W. M. Dantas, J. C. F. do Nascimento, M. V. da Silva, R. N. de Oliveira, and L. J. Pena, "In vitro and in vivo models for studying SARS-CoV-2, the etiological agent responsible for COVID-19 pandemic," Viruses, vol. 13, no. 3, p. 379, 2021.

[37] F. Wang, B. Pan, S. Xu et al., "A meta-analysis reveals the effectiveness of probiotics and prebiotics against respiratory viral infection," Bioscience Reports, vol. 41, no. 3, article BSR20203638, 2021. 